\title{
Morphological and functional characteristics of satellite glial cells in the peripheral nervous system
}

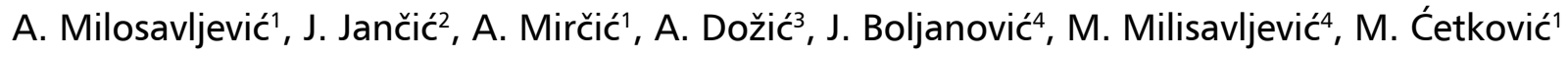 \\ 1/nstitute of Histology and Embryology, Faculty of Medicine, University of Belgrade, Serbia \\ ${ }^{2}$ Clinic of Neurology and Psychiatry for Children and Youth, Faculty of Medicine, University of Belgrade, Serbia \\ Institute of Anatomy, Faculty of Dental Medicine, University of Belgrade, Serbia \\ ${ }^{4}$ Laboratory for Vascular Anatomy, Institute of Anatomy, Faculty of Medicine, University of Belgrade, Serbia
}

[Received: 28 July 2020; Accepted: 12 November 2020; Early publication date: 5 December 2020]

\begin{abstract}
Satellite glial cells are specialised cells that form a functional perineuronal sheath around sensory ganglion neurons. There are a large number of studies that reveal the morphological and functional characteristics of these cells. Satellite glial cells have been studied both in intact ganglions and in tissue cultures, using light and transmission electron microscopy, immunohistochemical and other methods.

Satellite glial cells have polygonal form; they are mononuclear and have developed synthetic organelles, numerous receptors, adhesion molecules and ion channels, which enable them to interact with adjacent neurons, as well as transmit signals in the ganglions of the peripheral nervous system. Based on the literature data, satellite glial cells thanks to their characteristics can receive signals from other cells and react to changes in their surroundings.

Previous studies have investigated the potential role of satellite glial cells in the formation of the blood-nervous tissue barrier of the peripheral nervous system, as well as in the neuropathic pain genesis. Some recent discoveries support the fact that satellite glial cells can participate in controlling of local viral infections and protecting pseudounipolar neurons from mentioned infections. (Folia Morphol $2021 ; 80,4: 745-755)$
\end{abstract}

Key words: satellite glial cell, sensory ganglion, peripheral nervous system, pseudounipolar neuron

\section{INTRODUCTION}

A large number of scientists are researching the morphology and function of satellite glial cells and the number of studies is increasing and increasing. The application of histochemical and electron microscopic methods in satellite glial cell research can contribute to the identification of complex mechanisms of functioning of these cells, as well as their role in numerous diseases of the peripheral nervous system ganglions $[29,38,44,50,58]$

Satellite glial cells continually envelop neurons in peripheral nervous system ganglions. They completely encircle the ganglionic neurons in the form of one, and rarely two or three concentric layers, and together form morphological and functional units. The extracellular space between them and neurons has a diameter of

Address for correspondence: Dr. M. Ćetković, Institute of Histology and Embryology, Faculty of Medicine, University of Belgrade, Višegradska 26, 11000 Belgrade, Serbia, tel/fax: +381/11/3607-145, e-mail: milacetkovic06@gmail.com

This article is available in open access under Creative Common Attribution-Non-Commercial-No Derivatives 4.0 International (CC BY-NC-ND 4.0) license, allowing to download articles and share them with others as long as they credit the authors and the publisher, but without permission to change them in any way or use them commercially. 
only $20 \mathrm{~nm}$. Satellite glial cells are small, flattened, and interconnected by gap junctions $[47,49,50]$. The multiplication of satellite glial cells and the formation of several of their layers were registered after the experimental disruption of the axons of the ganglion neurons $[17,41]$.

The close relationships between satellite and ganglia cells also allow them to communicate with each other. One of the main messengers in this communication is nitrogen monoxide $[62,66]$. The protective role of satellite glial cells is also reflected in the secretion of individual neurotrophins, which help the survival of ganglion neurons $[66,74]$.

\section{MORPHOLOGICAL CHARACTERISTICS OF SATELLITE GLIAL CELLS}

\section{Short history of satellite glial cells}

Small perineuronal cells, which form a cell envelope around the body of neurons in sensory ganglions, were first mentioned by Valentine, in 1836 [67]. Even Ramon y Cajal himself named these cells several times [54]. In the late 1950s, the term satellite cell was widely accepted. As the term satellite cells also refers to skeletal muscle fibre progenitor cells, the authors agreed to name them satellite glial cells, with the recommendation that their exact location should be specified (e.g. satellite glial cells of trigeminal ganglion) [50].

Until the discovery of the electron microscope, various controversies arose as to whether the body of each neuron of the sensory ganglion was surrounded by satellite glial cells, since light microscopy has not always shown this in the past [29]. The advent of electron microscopy resolved these disputes, showing that the body of each nerve cell in the sensory ganglion is surrounded by a continuous sheath composed of discrete satellite glial cells [50]. Because the arrangement of satellite glial cells and the thickness of the sheath they build may vary in different areas and in different species, the fact that once these structures were below the resolution of light microscopy explains a different interpretation of the structure of the perineuronal sheath [44, 58]. Along with the development of the electron microscope, the resolution power of the light microscopy has grown, and even today, with light microscopy methods, at different cross-sectional levels, we can clearly see that satellite glial cells completely envelop sensory neurons [29, 38].

\section{Organization of the satellite glial cells in sensory ganglia}

In sensory ganglions, connective tissue sharply separates satellite glial cells' sheath belonging to one neuron from the sheaths belonging to other neurons (Figs. 1, 2). The outer surface of satellite glial cells, the one facing the interstitial connective tissue, is covered by a basal lamina (Figs. 1A, B). This surface is generally flatter than the one facing the neuron. In the peripheral parts of the cytoplasm of satellite glial cells, dense amorphous plaques may also be encountered, whose structure and function are still poorly understood. In the rabbit spinal ganglions, large voids (lacunae) have occasionally been observed, just below the outer surface of the satellite glial cell plasmalemma [49]. It has been observed that cilia and microvilli can be projected into these voids [49]. These lacunar spaces have been observed only in animal models and their significance has not been demonstrated so far [49].

Satellite glial cells have polygonal form; they are mononuclear (Figs. 1C, D), and have developed synthetic organelles, numerous receptors, adhesion molecules and ion channels, which allow them to interact with adjacent neurons as well as to transmit signals in the ganglions of the peripheral nervous system [17]. They have very expressed granular endoplasmic reticulum, mitochondria, Golgi apparatus, lysosomes, peroxisomes [18, 20,43]. The expressed cytoskeletal components are microtubules and intermediate filaments, as well as occasionally present cellular inclusions such as lipofuscin granules $[5,44,45]$.

The cell membranes of satellite glial cells differ in thickness from the cell membranes of neurons [50]. In cell membranes of satellite glial cells treated with the freeze-section procedure, sets of orthogonally arranged particles were found [42]. The distance between these particles is about $7 \mathrm{~nm}$ [16]. Similar structures have been observed in astrocytes, ependymal cells of higher vertebrates, while they have never been recognised within the cell membranes of oligodendrocytes or neurons $[25,55]$. These structures are much rarer in satellite glial cell membranes than in astrocyte membranes [25]. These structures were later shown to be constructed from the aquaporin-4 protein, a membrane protein involved in the transport of water across the cell membrane $[55,69]$.

Satellite glial cells possess long and branched cytoplasmic extensions, especially on surfaces facing neurons [64]. Because of the large number of cytoplasmic extensions of both neurons and satellite glial cells, it is very difficult to determine precisely the boundary between neurons and satellite glial cells. In the past, these cytoplasmic extensions were thought 

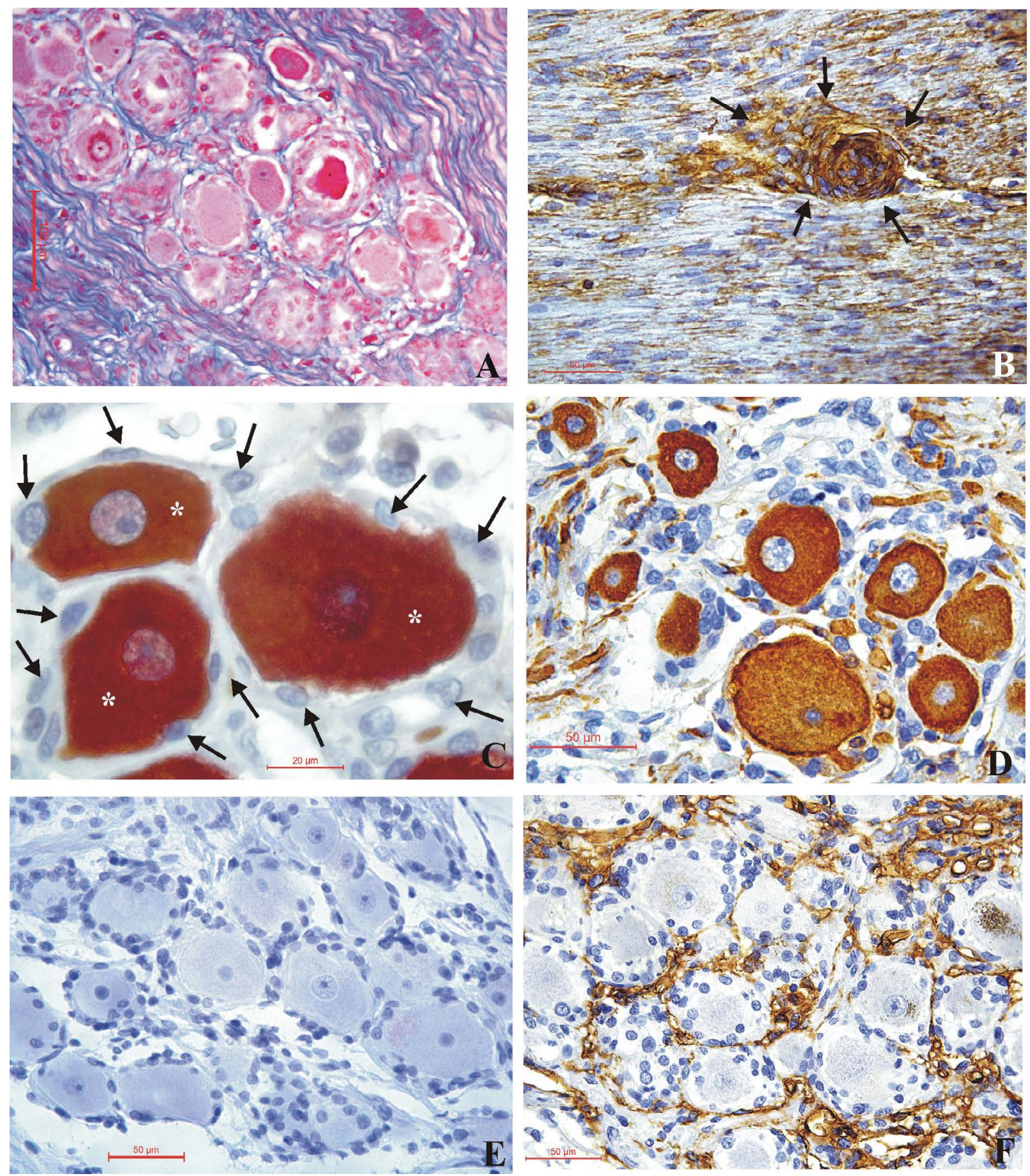

Figure 1. Histological characteristics of the human sensory ganglia; A. Dorsal root, spinal sensory ganglion containing clusters of round and oval neurons surrounded by many satellite glial cells (SGC). Fascicles of nerve fibres (red) are followed by bundles of collagen fibres (blue) which also separate SGC-neuron units (Trichrome Masson staining); B. Vimentin immunoreactivity detected in the cytoplasm of SGC (arrows), covering an ectopic, displaced neuron in the trigeminal nerve; C. Intense neuron specific enolase immunoreactivity in neurons (asterisks) of the trigeminal ganglion; SGC (arrows) are negative; D. Immunoreactivity against neurofilament protein in pseudounipolar neurons of the trigeminal ganglion; SGC do not show immunoreactivity; E. The cell bodies of foetal trigeminal ganglion (32 weeks gestational age) surrounded by numerous SGC (Haematoxylin staining); F. Numerous capillaries immunostained against CD34 (endothelial cells protein) around the SGC covering trigeminal neurons.

to be the result of deformation of satellite glial cells due to the use of different procedures [46]. Even after prolonged in vitro cultivation of sensory ganglions, satellite glial cells have been shown to retain shapes similar to those observed in in vivo conditions $[5,64$, 73]. Their cytoplasmic extensions may be ring-shaped 

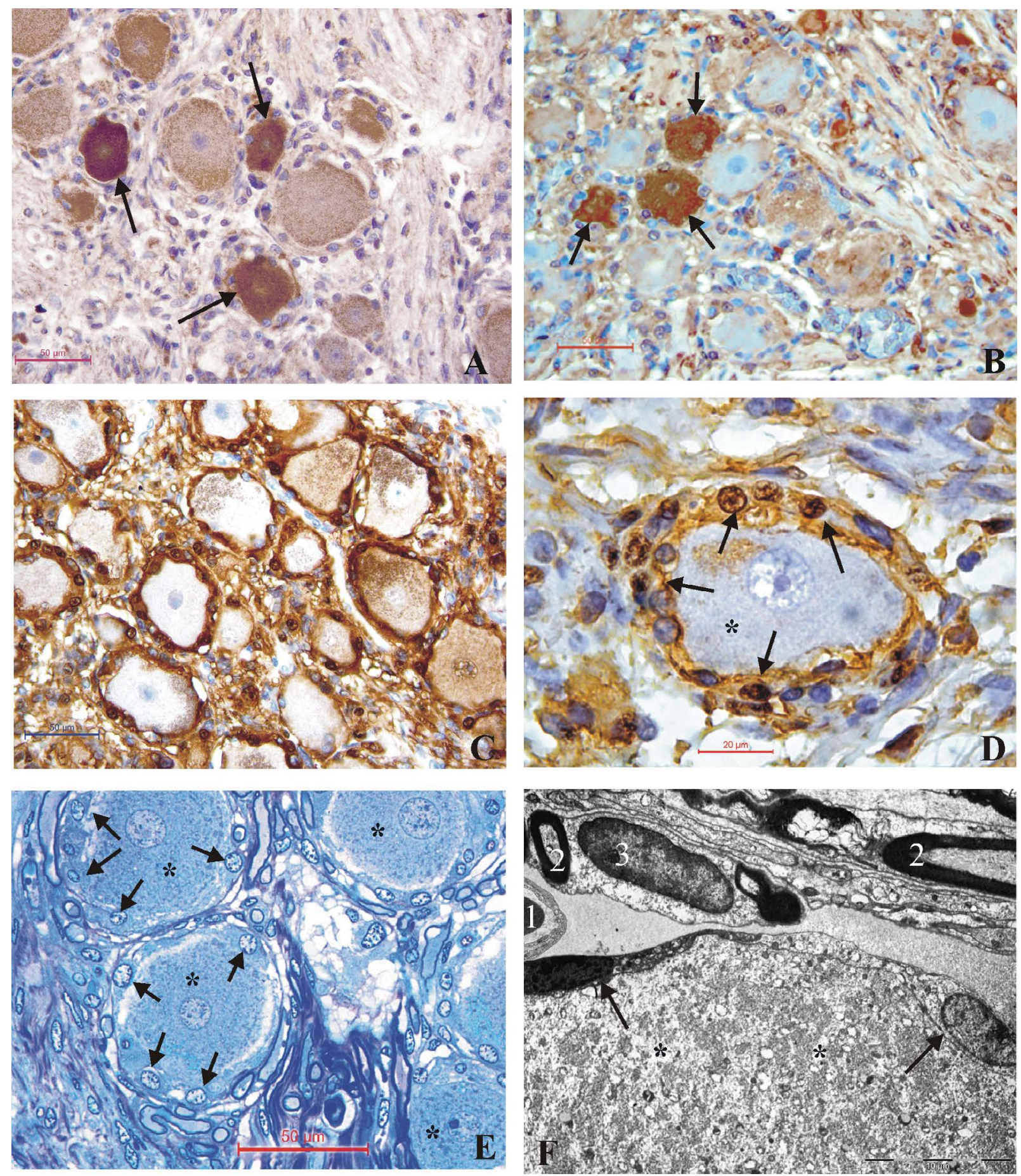

Figure 2. Histology of the sensory ganglia; A. Calcitonin gene related peptide (CGRP) immunoreactivity in small to medium-sized neurons of the human dorsal root ganglion (arrows); satellite glial cells (SGC) are not stained; B. Substance P immunoreactivity in small to medium-sized neurons of the human geniculate ganglion (arrows); SGC are negative; C. S-100 proteins immunoreactivity was detected in all SGC, but in few neurons of the human trigeminal ganglion; D. Higher magnification of SGC positive for S-100 proteins (arrows), and negative human ganglionic trigeminal cell (asterisk); E. Semithin section of a rat trigeminal ganglion; trigeminal neurons (asterisks) and SGC (arrows) are shown (Toluidine blue staining); $F$. Electron microscopy of the section through the trigeminal neuron (asterisks) of a rat and two SGC (arrows) in close contact; 1 - capillary; 2 - myelinated nerve fibres; 3 - Schwann cell.

or may have a lamellar shape [5, 73]. Extensions in cilia are also described in the literature [45]. These cilia lack a central microtubule pair and show only nine pairs of peripheral microtubules, as well as in neurons, in Schwann cells and astrocytes [45]. Finding specific receptors on the solitary cilia of particular 
neurons supports the hypothesis that they are sensory specialisations $[8,26,76]$.

\section{Embryonic development of the satellite glial cells}

Satellite glial cells of the sensory ganglia share a common embryonic origin with neurons [33]. Satellite glial cells of the spinal ganglia originate from the neural crest, and partly from neuroepithelial cells that migrate from the spinal cord $[27,61]$.

Levi [33], who has studied ganglion development in many species, concluded that neuronal differentiation always precedes differentiation of satellite glial cells in sensory ganglions. In the earliest stages of sensory ganglion development, undifferentiated, rounded cells at different stages of cell division can be observed [33].

These still undifferentiated cells may be single, or in small groups, among still immature neurons [44]. In the early stages of embryonic development, one satellite glial cell is connected to multiple neurons, and then, as development takes place, each nerve cell is completely enveloped by satellite glial cells, which form a functional sheath around it (Fig. 1E) [44].

\section{Satellite glial cells: the blood-nervous tissue barrier of the peripheral nervous system}

Due to the characteristic arrangement of satellite glial cells and their relationships with the surrounding structures, we can conclude that all the molecules from the blood vessels of the interstitial connective tissue must pass through the sheath built by satellite glial cells to reach neurons (Fig. 1F, 2F) [1]. Neurons in the sensory ganglion lack the presence of the blood-nervous tissue barrier (as it is present in the central nervous system). As a consequence, the satellite glial cells' sheath is the only to control the transfer of molecules to neurons [22]. Therefore, it is reported in literature, that satellite glial cells represent the blood-nervous tissue barrier of the peripheral nervous system, although there is a partial movement of substances from the connective tissue vessels to the neuron $[22,65]$. In the 1960s, Novikof et al. [39] and a group of scientists proved the presence of enzymes such as acetylcholinesterase and nucleoside transferase in the spaces between satellite glial cells and neurons [65]. The origin of these two enzymes has been discussed a lot and the most accepted is the theory that these enzymes are generated in the bodies of neurons and then released into mentioned intercellular spaces at axonal terminals [39]. These enzymes have been hypothesized to have hydrolytic properties, due to which they could degrade substances that have a potentially negative effect on neural activities [39]. Hypotheses have also been claimed for the interaction of these enzymes with transport ATPases; however, there are is more detailed data on this topic in the literature $[39,65]$. The striking length and curvature of the path between the basal lamina and the neural surface slows the diffusion of the substances through the perineuronal sheath [22]. The barrier function of the perineuronal sheath may be particularly important when neuronal moving substances are toxic. In old age, this function may be impaired [39]. Satellite glial cells are thought to influence the composition and density of these enzymes and other substances in intercellular spaces, which can control the flow of matter to the neuron they surround [39].

\section{Molecular markers of satellite glial cells}

We can safely say that satellite glial cells express a large number of proteins and adhesion molecules on their surface $[2,31,36,40,56,59,62,63,70,78]$. Molecular markers are essential for the identification of satellite glial cells, especially when intercellular relationships are disturbed (e.g. in dissociated cell culture) (Figs. 2A, B) [59]. Among these markers is protein $\mathrm{S100}$, which is also present in Schwann cells (Figs. 2C, D) [59]. The multi-selective markers of satellite glial cells are glutamate-aspartate transporter and glutamine synthetase [23].

The guanylate cyclase is also located within satellite glial cells [31]. This enzyme is activated by nitric oxide (NO) released by neurons after an axonal lesion [62]. The NO precursor, arginine, has been detected in satellite glial cells, so satellite cells are thought to supply the neurons with the arginine required to produce NO [2]. Other molecules that synthesize satellite glial cells are cytokine tumour necrosis factor-alpha $[40,63]$ and prostaglandins [70].

\section{Relationships between satellite glial cells}

In certain regions of the sensory ganglions, adjacent satellite glial cells interconnect, while in other regions, forming a sheath around the common cell, their lamellar extensions overlap [50]. Where numerous lamellar extensions overlap, multiple lamellar extensions may belong to the same cell, so it can sometimes be observed that the number of these lamellar extensions is greater than the number of satellite glial cells themselves (Figs. 2E, F) $[49,50]$. 
Cracks between the membranes of adjacent satellite glial cells can measure 15 to $20 \mathrm{~nm}$ in diameter [49]. These cracks open into a narrow space below the basal lamina at one end, and into a narrow space between neurons and closely spaced satellite glial cells at the other $[44,49]$. This potential pathway between the interstitial connective tissue of the ganglia and the surface of the neuron usually has a long and twisted flow, even in areas where the perineuronal sheath is thin, and is thought to have some functional significance [44, 49,50].

Satellite glial cells are linked to other satellite glial cells within the same perineuronal sheath by adherent, occludent connections and nexuses $[35,47]$. Adherent connections are small structures that resemble a button. These compounds have also been described between adjacent Schwann cells [13]. Nexuses, as connections present between satellite glial cells have been discovered by tissue freezing techniques [42]. These connections have also been found in satellite glial cells of autonomic ganglions [14]. The presence of structures similar to occludent connections has also been demonstrated [14]. Specifically, in some studies, thin filament structures called strands have been observed within the plasmalemma of satellite glial cells, which exhibit the same morphological characteristics as those structures and proteins that create occludent connections in other tissues $[14,47]$. They were detected by the freeze-section technique, at the plasmalemma level of satellite glial cells [14]. Some scientists also call them macula occludens [14]. Such threads are interpreted as the basic elements of tight, occludent connections. Their presence has also been demonstrated in satellite glial cells of autonomic ganglions [14, 70].

All of the previously mentioned types of connections probably contribute to the adhesion between satellite glial cells [42, 48]. Moreover, these relationships have other important roles. The inner diameter of the nexus channel (about $1.2 \mathrm{~nm}$ in size) not only allows the intercellular passage of ions, but also the transfer of molecules with molecular weights up to about $1 \mathrm{kD}$ (e.g. signalling molecules, amino acids and glucose) $[14,42,48]$. Information about the compounds and connections that form satellite glial cells are scarce.

Connexin-43 has been identified in satellite glial cells of trigeminal ganglions of rats [71], murine spinal ganglions [53], as well as in guinea pig ganglions and human spinal ganglions [35]. In perineuronal satellite cells of the spinal ganglions connexin-36 is also identified [51].

\section{FUNCTIONAL CHARACTERISTICS OF SATELLITE GLIAL CELLS}

Perineuronal homeostasis

Satellite glial cells play a major role in homeostasis of the perineuronal environment [49]. Neural activity causes an increase in extracellular potassium concentration, resulting in increased nerve excitability [23]. Satellite glial cells on their surface express $\mathrm{K}^{+}$ channels, which play a central role in extracellular potassium uptake $[23,77]$. Thanks to nexuses, satellite glial cells rapidly distribute potassium ions among adjacent cells, thereby establishing perineuronal homeostasis [24].

Glutamate is the major neurotransmitter present in sensory ganglion neurons, but it is important to emphasize that high levels of glutamate are neurotoxic [23]. Satellite glial cells express glutamate transporters on their surface; so that if high concentrations of glutamate are released from neurons into the perineuronal space, it is satellite glial cells that will remove excess glutamate from mentioned area $[6,23,60]$. In this way, they maintain glutamate concentrations below neurotoxic levels in the perineuronal microenvironment [6]. Satellite glial cells, which contain the enzyme glutamine synthetase, convert glutamate to glutamine $[23,60]$. Glutamine is then returned to neurons and converted again to glutamate, using their phosphate glutaminases [60]. Since neurons use glutamate for synaptic transmission, we can say that the metabolism of sensory ganglion neurons itself is largely dependent on their interaction with neighbouring satellite glial cells [6].

In addition to the glutamate transporter, satellite glial cells also express gamma-aminobutyric acid receptors on their surface, which can induce the depolarisation of neurons by sensory ganglions $[23,60]$. Due to the existence of these transporters, satellite glial cells can control the concentration of gamma-aminobutyric acid in the perineuronal microenvironment, and thus protect the neurons themselves from the effects of excessive concentrations of this acid [4, 79].

\section{Neuroprotective role of satellite glial cells}

The neuroprotective role of satellite glial cells has been repeatedly demonstrated [64]. The NO-cGMP pathway plays a major role in neuronal protection [62, 66]. NO is generated in the bodies of neurons, thanks to the enzyme NO synthetase, which is present in the bodies of the neurons of the dorsal roots of the spinal ganglion $[62,66]$. Whether NO plays a protective or 
toxic role depends on its concentration as well as on its receptor concentration, soluble guanylate cyclase (sGC) [62]. Across the NO receptor, cyclic guanosine monophosphate (cGMP) activation occurs in satellite glial cells, and it is thought that its generation by satellite glial cells may limit various degenerative changes at the neuronal level and facilitate their survival in pathological conditions $[62,66]$. Specifically, in nerve injury, many more ganglion neurons express the presence of NO synthase, whereas satellite glial cells express cGMP [66]. Thus, activation of cGMP, v62 the receptor for NO, can limit or even reverse degenerative changes at the neuronal level $[62,66]$. It is thought that the interaction between NO, sGC and cGMP expressed by satellite glial cells facilitates the survival of injured neurons [66].

There are also studies showing that inhibition of NO synthase leads to an increase in degenerative changes in neurons and glia [62]. In recent years, several studies have reported the antiapoptotic effect of NO and CGMP in cultures of neurons and non-neuronal cells. Although these observations suggest that the NO-cGMP pathway is crucial in protecting neurons, the precise mechanism of these processes is poorly understood [66].

\section{Phagocytic activity of satellite glial cells}

Based on previous studies, it has been observed that fragments of degenerate cells are found within satellite glial cells, both in the sensory and autonomic ganglions [37, 48, 52]. These findings suggest that satellite glial cells have phagocytic capacity, as demonstrated by culturing these cells in vitro $[75,77]$.

\section{The role of satellite glial cells in the immune system}

Satellite glial cells in the ganglion also have immune system functions [68]. They have a leukocyte phenotype, with macrophage characteristics so that they control local virus-specific $T$ cells and protect ganglion cells infected with herpes virus from damage as well as uninfected cells from infection [68].

\section{Satellite glial cells and herpes simplex virus}

The most studied viral infection affecting the sensory ganglion is the herpes simplex virus (HSV) infection $[10,15,21,82]$. During initial infection, the virus travels by retrograde axonal transport to the bodies of sensory ganglion neurons, in which latent infection is established [10]. Sensory ganglion neurons are capa- ble of supporting complete viral replication with the production of mature enveloped particles [10, 15]. Unlike neurons, HSV infections are rarely detected in satellite glial cells in vivo; these cells have been shown to contain only undeveloped viral particles $[10,21]$. In vivo, sensory ganglion neurons typically exhibit the following structural changes associated with HSV infection: nucleolus disruption and nuclear membrane reduplication [10]. Structural changes of organelles have been observed less frequently (some changes in mitochondria and dilatation of cisterns of the endoplasmic reticulum have been observed) [82].

In vivo neurons infected with herpes simplex persist, while in culture they are destroyed by the virus [81]. Infected neurons are usually found scattered within the ganglion. The virus does not spread from infected neurons to adjacent neurons probably because satellite cells form a barrier to the interneuronal spread of the virus within the ganglion [32]. In the vestibular ganglion, the viral particles cannot propagate from neurons to satellite glial cells because they cannot pass through the distended myelin sheath [72]. In the sensory ganglions of experimentally infected mice, satellite glial cells proliferate, and an increase in the number of these cells probably facilitates neuronal survival [15].

\section{Satellite glial cells and herpes zoster virus}

In acute varicella-zoster virus infection, in sensory ganglions, both neurons and satellite glial cells contain viral particles [80]. In the latent phase, viral particles are localised in sensory ganglion neurons and rarely in satellite glial cells [34]. Varicella-zoster virus (VZV) can induce fusion formation between a neuron and its satellite glial cells [57].

Specifically, there are studies detailing the mechanisms of action of VZV itself, as well as the supporting role of satellite glial cells in replication of this virus [57]. Nucleocapsid formation occurs in the bodies of neurons and satellite glial cells as well as virions located in cytoplasmic vacuoles [57]. Certain varicella zoster proteins (immediate-early [IE]) regulatory proteins, early ORF47 kinase, glycoprotein $\mathrm{gE}$ ) are expressed both on the surface of satellite glial cells and on the surface of VZV-infected sensory neurons [57]. Viral genomic DNA has been detected in both nuclei of infected neurons and in nuclei of satellite glial cells that express a specific type of IE protein, called IE63 [57], on its surface. These surface proteins are thought to result in the fusion of cell membranes of satellite glial cells and neurons, as well as the 
transfer of certain proteins and virions from neurons to satellite glial cells and vice versa [57]. This fusion allows rapid replication of the virus in the satellite glial cells themselves, and, much more importantly, the faster spread of the virus to the uninfected neurons (supported by the very fact that one sensory neuron surrounds a larger number of satellite glial cells, and hence the spread of the virus faster and more efficient) [57]. Direct VZV infection of satellite glial cells could also occur during primary VZV infection, when the virus can gain access to sensory ganglions via the haematogenous pathway via VZV infection of T cells $[15,57]$. This pathway of spread increases the ability of the virus to establish latency [57].

\section{The role of satellite glial cells in neuropathic pain}

Peripheral nerve injury and inflammation of peripheral tissues increase the excitability of sensory ganglion neurons, thereby causing their spontaneous activity [7]. This is a major factor in the generation and maintenance of neuropathic pain [9]. As described previously, in the sensory ganglions of adult vertebrates, each nerve cell body is tightly enveloped in a single sheath of satellite glial cells, which are completely surrounded by connective tissue, thus forming a discrete unit [30]. Therefore, satellite glial cells are the only cells in direct contact with the bodies of sensory neurons. Because satellite glial cells are highly sensitive to changes in neurons, and because they have the ability to modulate neural excitability, these cells are thought to play an important role in the development and maintenance of neuropathic pain $[12,19,71]$. There are several mechanisms underlying the contribution of satellite glial cells to the hyperexcitability of sensory ganglion neurons, and thus to the development and maintenance of neuropathic pain. Because neurons are the target of lesions, changes in satellite glial cells occur secondary to neuronal changes, upon activation of signalling mechanisms between damaged neurons and associated satellite glial cells. Neuron-released adenosine triphosphate can activate purinergic receptors on satellite glial cells, which can lead to cytokine synthesis (e.g., interleukin $1 p$ and tumour necrosis factor-alpha) [12]. Thus released cytokines can enhance nerve excitability, as demonstrated in several experiments. There is research in which topical application of the interleukin 1 receptor antagonist has acted on the physiological threshold of sensory ganglion neurons and allowed the reduction of peripheral neuropathic pain [12].
Peripheral nerve injury and facial inflammation increase the excitability of trigeminal ganglion neurons $[19,71]$. Under such conditions, these neurons release $\mathrm{K}^{+}$into the perineuronal microenvironment $[23,77]$. The $\mathrm{K}^{+}$concentration within this space is primarily regulated by the $\mathrm{K}^{+}$channel Kir4.1, which is expressed by satellite glial cells [11]. However, peripheral nerve injury and facial inflammation, regulated by Kir4.1 channels expressed on satellite glial cells, can result in disruption of $\mathrm{K}^{+}$homeostasis within the perineuron microenvironment $[11,23,77]$. Increasing extracellular $\mathrm{K}^{+}$leads to an increase in neural excitability, which may further exacerbate neuropathic pain $[11,77]$.

Taken together, all these mechanisms indicate that Kir4.1 channels, expressed on satellite glial cells, have a role in the development and maintenance of neuropathic pain. Since the Kir4.1 channel has been shown to be involved in glutamate homeostasis, it is thought that it could contribute to neuropathic pain and this additional mechanism [11]. If glutamate is the major neurotransmitter of sensory ganglion neurons released into the perineuronal microenvironment, impaired glutamate homeostasis caused by reduction of the Kir4.1 channel may lead to an increase in extracellular glutamate and consequently to an increase in neural excitability [11].

Certain studies have shown that the number of communicative connections between satellite glial cells increases after injury to the nerves themselves $[17,41]$. An increased number of connections between satellite glial cells may cause changes in the perineuronal microenvironment and thus contribute to the creation or maintenance of neuropathic pain $[7,17]$. As evidence of support to this hypothesis, research has been conducted that showed that communicative linkage blockers restore nerve excitability to baseline, control levels and thus reduce neuropathic pain [7, 12]. Moreover, the application of polymerisation chain reaction method and the use of informational RNA, as a connexin neutralizer 43, a major structural component of satellite glial cell communicative connections, reduce the number of these connections at the trigeminal ganglion level and produces analgesia [53]. Following nerve injury or inflammation, neurotrophic factors increase the excitability of sensory ganglion neurons and thus contribute to neuropathic pain [28]. Satellite glial cells also express neurotrophic factors and their receptors on their surfaces, thus regulating neuropathic pain $[74,83]$. There is also an additional mechanism 
by which satellite glial cells may be involved in the creation and maintenance of neuropathic pain. Over the past decade, a large number of studies have been conducted on the relationships and connections between glial cells and neuropathic pain $[7,9,11,12$, $19,30,71]$. Satellite glial cells have been found to undergo different changes when neuropathic pain occurs. Each of these changes inspired a specific hypothesis about the mechanisms by which satellite glial cells contribute to the development and maintenance of neuropathic pain. However, decisive experiments that confirm or refute these hypotheses are lacking, and therefore this topic itself is insufficiently elucidated and confirmed $[7,9,11,12]$.

There has been recently conducted study which started examining the role of satellite glial cells in systemic inflammation [3]. It has been hypothesized that satellite glial cells must play a role in chronic pain and that systemic inflammatory responses lead to changes in these cells, as do local injury. The study was conducted in mice whose systemic inflammation was induced by lipopolysaccharide injection intraperitoneally [3]. Satellite glial cells of mice dorsal ganglions were detected by immunohistochemical methods and electron microscopy [3,44]. Within days of lipopolysaccharide injection, changes were observed in satellite glial cells, in the form of a large increase in the number of their cellular extensions, as well as an increase in the communicative connections between them. Twice the sensitivity of satellite glial cells to ATP has also been observed. The conclusion of this study is that changes in satellite glial cell levels are caused by systemic inflammation, similar to those caused by local injury [3].

\section{CONCLUSIONS}

Satellite glial cells are a structure much more significant rather than simple morphological enclosure of the neuron. A continuous layer of satellite glial cells protects neurons and maintains homeostasis in their microenvironment, which corresponds to a form of blood-nervous tissue barrier.

Satellite glial cells have many different receptors binding, among other things, various substances with nociceptive effect. After excitation, the satellite glial cells release molecules of inflammation, cytokines and NO, leading to sensitisation and activation of neurons. Thus, activation of neurons and satellite glial cells in a certain part of the ganglion triggers an inflammatory cascade involving other neurons and satellite glial cells. This phenomenon was observed in the development of the pain syndromes and could be also the possible underlying mechanism of chronic pain. Subsequently, the sGC are seen as potential targets in the practical application of the pain therapy.

The progress in understanding the sGC morphology, and increasing knowledge of SGC capacities in ganglionic neurons homeostasis, both enable new perspectives of further research in this field. First, sGC have immune system properties. They control local virus-specific $\mathrm{T}$ cells and protect ganglionic cells. Protective function of $s G C$ needs to be evaluated in viral infections other than herpes virus, for example in the very topical and deadly coronavirus infection. Second, instead of using animal cells, sGC from human sensory ganglions, may represent a promising objective for therapeutic studies in pain research in experimental laboratories. Third, a comparative study between $\mathrm{sGC}$ from different types of ganglions, particularly autonomic, would be a promising research with original scientific importance.

\section{Funding}

This work was supported by grant No. 200110 from the Ministry of Education, Science and Technological Development of the Republic of Serbia.

\section{Conflict of interest: None declared}

\section{REFERENCES}

1. Anzil AP, Blinzinger K, Herrlinger $H$. Fenestrated blood capillaries in rat cranio-spinal sensory ganglia. Cell Tissue Res. 1976; 167(4): 563-567, doi: 10.1007/BF00215185, indexed in Pubmed: 1083768.

2. Aoki E, Semba R, Kashiwamata S. Evidence for the presence of L-arginine in the glial components of the peripheral nervous system. Brain Res. 1991; 559(1): 159-162, doi: 10.1016/00068993(91)90300-k, indexed in Pubmed: 1782556.

3. Blum E, Procacci $P$, Conte $V$, et al. Systemic inflammation alters satellite glial cell function and structure. A possible contribution to pain. Neuroscience. 2014; 274: 209-217, doi: 10.1016/j. neuroscience. 2014.05.029.

4. Brown DA, Galvan M. Influence of neuroglial transport on the action of gamma-aminobutyric acid on mammalian ganglion cells. Br J Pharmacol. 1977; 59(2): 373-378, doi: 10.1111/ j.1476-5381.1977.tb07502.x, indexed in Pubmed: 189874.

5. Bunge $M B$, Bunge RP, Peterson ER, et al. A light and electron microscope study of long-term organized cultures of rat dorsal root ganglia. J Cell Biol. 1967; 32(2): 439-466, doi: 10.1083/ jcb.32.2.439, indexed in Pubmed: 10976233.

6. Carozzi VA, Canta A, Oggioni N, et al. Expression and distribution of 'high affinity' glutamate transporters GLT1, GLAST, EAAC1 and of GCPII in the rat peripheral nervous system. J Anat. 2008; 213(5): 539-546, doi: 10.1111/j.14697580.2008.00984.x, indexed in Pubmed: 19014361.

7. Cherkas PS, Huang TY, Pannicke T, et al. The effects of axotomy on neurons and satellite glial cells in mouse trigeminal ganglion. Pain. 2004; 110(1-2): 290-298, doi: 10.1016/j. pain.2004.04.007, indexed in Pubmed: 15275779.

8. Chudler EH, Anderson LC, Byers MR. Trigeminal ganglion neuronal activity and glial fibrillary acidic protein immunoreactivity after inferior alveolar nerve crush in the adult rat. Pain. 1997; 
73(2): 141-149, doi: 10.1016/\$0304-3959(97)00088-2, indexed in Pubmed: 9415499.

9. Devor M, Seltzer Z. Pathophysiology of damaged nerves in relation to chronic pain. In: Wall PD, Melzack R (eds) Textbook of pain. Churcill Livingston, London 1999: 129-164.

10. Dillard SH, Cheatham WJ, Moses HL. Electron microscopy of zosteriform herpes simplex infection in the mouse. Lab Invest. 1972; 26(4): 391-402, indexed in Pubmed: 4336537.

11. Djukic B, Casper KB, Philpot BD, et al. Conditional knock-out of Kir4. 1 leads to glial membrane depolarization, inhibition of potassium and glutamate uptake, and enhanced short-term synaptic potentiation. J Neurosci. 2007; 27(42): 11354-11365, doi: 10.1523/ JNEUROSCI.0723-07.2007, indexed in Pubmed: 17942730.

12. Dubový $P$, Klusáková I, Svízenská I, et al. Satellite glial cells express IL-6 and corresponding signal-transducing receptors in the dorsal root ganglia of rat neuropathic pain model. Neuron Glia Biol. 2010; 6(1): 73-83, doi: 10.1017/S1740925X10000074, indexed in Pubmed: 20519054.

13. Eames RA, Gamble HJ. Schwann cell relationships in normal human cutaneous nerves. J Anat. 1970; 106(Pt 3): 417-435, indexed in Pubmed: 5423938.

14. Elfvin LG, Forsman C. The ultrastructure of junctions between satellite cells in mammalian sympathetic ganglia as revealed by freeze-etching. J Ultrastruct Res. 1978; 63(3): 261-274, doi: 10.1016/s0022-5320(78)80051-3, indexed in Pubmed: 682227.

15. Elson K, Speck P, Simmons A. Herpes simplex virus infection of murine sensory ganglia induces proliferation of neuronal satellite cells. J Gen Virol. 2003; 84(Pt 5): 1079-1084, doi: 10.1099/ vir.0.19035-0, indexed in Pubmed: 12692271.

16. Gotow T, Yoshikawa H, Hashimoto PH. Distribution patterns of orthogonal arrays and alkaline phosphatase in plasma membranes of satellite cells in rat spinal ganglia. Anat Embryol (Berl). 1985; 171(2): 171-179, doi: 10.1007/BF00341411, indexed in Pubmed: 3985366.

17. Hanani M. Satellite glial cells in sensory ganglia: from form to function. Brain Res Brain Res Rev. 2005; 48(3): 457-476, doi: 10.1016/j.brainresrev.2004.09.001, indexed in Pubmed: 15914252.

18. Hanker JS, Romanovicz DK, Moore GH. Peroxisomes in satellite, Schwann and laminarcells associated with trigeminal sensory neurons. J Cell Biol. 1974; 63: 131a.

19. Herman SP, Klein R, Talley FA, et al. An ultrastructural study of methylmercury-induced primary sensory neuropathy in the rat. Lab Invest. 1973; 28(1): 104-118, indexed in Pubmed: 4569929.

20. Hess $A$. The fine structure of young and old spinal ganglia. Anat Rec. 1955; 123(4): 399-423, doi: 10.1002/ar.1091230403, indexed in Pubmed: 13292772.

21. Hill TJ, Field HJ. The interaction of herpes simplex virus with cultures of peripheral nervous tissue: an electron microscopic study. J Gen Virol. 1973; 21: 123-133, doi: 10.1099/0022-131721-1-123, indexed in Pubmed: 4357369.

22. Holtzman E, Peterson ER. Uptake of protein by mammalian neurons. J Cell Biol. 1969; 40(3): 863-869, doi: 10.1083/ jcb.40.3.863, indexed in Pubmed: 5765774.

23. Hösli E, Hösli L. Autoradiographic localization of the uptake of $[3 \mathrm{H}]-\mathrm{GABA}$ and $[3 \mathrm{H}] \mathrm{L}-\mathrm{glutamic}$ acid in neurones and glial cells of cultured dorsal root ganglia. Neurosci Lett. 1978; 7(2-3): 173-176, doi: 10.1016/0304-3940(78)90163-5.

24. Huang TY, Cherkas PS, Rosenthal DW, et al. Dye coupling among satellite glial cells in mammalian dorsal root ganglia. Brain Res. 2005; 1036(1-2): 42-49, doi: 10.1016/j.brainres.2004.12.021, indexed in Pubmed: 15725400.

25. Jessen KR, Thorpe R, Mirsky R. Molecular identity, distribution and heterogeneity of glial fibrillary acidic protein: an immunoblotting and immunohistochemical study of Schwann cells, satellite cells, enteric glia and astrocytes. J Neurocytol. 1984; 13(2): 187-200, doi: 10.1007/BF01148114, indexed in Pubmed: 6726286.

26. Jessen KR, Thorpe R, Mirsky R. Molecular identity, distribution and heterogeneity of glial fibrillary acidic protein: an immunoblotting and immunohistochemical study of Schwann cells, satellite cells, enteric glia and astrocytes. J Neurocytol. 1984; 13(2): 187-200, doi: 10.1007/BF01148114, indexed in Pubmed: 6726286.

27 . Jones D. Studies on the origin of sheath cells and sympathetic ganglia in the chick. Anat Rec. 1939; 73(3): 343-357, doi: 10.1002/ar.1090730309.
28. Julius D, Basbaum Al. Molecular mechanisms of nociception. Nature. 2001; 413(6852): 203-210, doi: 10.1038/35093019, indexed in Pubmed: 11557989.

29. King JS. A light and electron microscopic study of perineuronal glial cells and processes in the rabbit neccortex. Anat Rec. 1968; 161(1): 111-123, doi: 10.1002/ar.1091610112, indexed in Pubmed: 4174123.

30. Krawczyk WS, Wilgram GF. Hemidesmosome and desmosome morphogenesis during epidermal wound healing. J Ultrastruct Res. 1973; 45(1): 93-101, doi: 10.1016/s0022-5320(73)90035-x, indexed in Pubmed: 4750505.

31. Kummer W, Behrends S, Schwarzlmüller T, et al. Subunits of soluble guanylyl cyclase in rat and guinea-pig sensory ganglia. Brain Res. 1996; 721(1-2): 191-195, doi: 10.1016/00068993(96)00097-2, indexed in Pubmed: 8793100.

32. LaVail JH, Topp KS, Giblin PA, et al. Factors that contribute to the transneuronal spread of herpes simplex virus. J Neurosci Res. 1997; 49(4): 485-496, indexed in Pubmed: 9285524.

33. Levi G. La capsula delle cellule dei gangli sensitivi. Penetrazione di fibre collagene nel loro protoplasma. Monit Zool Ital. 1907; 18: 153-158.

34. Levin MJ, Cai GY, Manchak MD et al Varicella-zoster virus DNA in cells isolated from human trigeminal ganglia. J Virol. 2003; 77(12): 6979-6987, doi: 10.1128/jvi.77.12.6979-6987.2003, indexed in Pubmed: 12768016.

35. Liu W, Glueckert R, Linthicum FH, et al. Possible role of gap junction intercellular channels and connexin 43 in satellite glial cells (SGCs) for preservation of human spiral ganglion neurons: a comparative study with clinical implications. Cell Tissue Res. 2014; 355(2): 267-278, doi: 10.1007/s00441-013-1735-2, indexed in Pubmed: 24241398.

36. Magnusson S, Ekström J, Elmér E, et al. Heme oxygenase-1, heme oxygenase- 2 and biliverdin reductase in peripheral ganglia from rat, expression and plasticity. Neuroscience. 1999; 95(3): 821-829, doi: 10.1016/s0306-4522(99)00466-2.

37. Matthews MR, Raisman G. A light and electron microscopic study of the cellular response to axonal injury in the superior cervical ganglion of the rat. Proc R Soc Lond B Biol Sci. 1972; 181(1062): 43-79, doi: 10.1098/rspb.1972.0040, indexed in Pubmed: 4402334.

38. Moses HL, Beaver DL, Ganote CE. Electron microscopy of the trigeminal ganglion. I. Comparative ultrastructure. Arch Pathol. 1965; 79: 541-556, indexed in Pubmed: 14301977.

39. Novikoff AB, Quintana N, Villaverde $\mathrm{H}$, et al. Nucleoside phosphatase and cholinesterase activities in dorsal root ganglia and peripheral nerve. J Cell Biol. 1966; 29(3): 525-545, doi: 10.1083/ jcb.29.3.525, indexed in Pubmed: 4225492.

40. Ohtori S, Takahashi K, Moriya H, et al. TNF-alpha and TNF-alpha receptor type 1 upregulation in glia and neurons after peripheral nerve injury: studies in murine DRG and spinal cord. Spine (Phila Pa 1976). 2004; 29(10): 1082-1088, doi: 10.1097/00007632200405150-00006, indexed in Pubmed: 15131433.

41. Pannese E, Ledda M, Cherkas PS, et al. Satellite cell reactions to axon injury of sensory ganglion neurons: increase in number of gap junctions and formation of bridges connecting previously separate perineuronal sheaths. Anat Embryol (Berl). 2003; 206(5): 337-347, doi: 10.1007/s00429-002-0301-6, indexed in Pubmed: 12698360

42. Pannese $E$, Luciano $L$, lurato $S$, et al. Intercellular junctions and other membrane specializations in developing spinal ganglia: a freeze-fracture study. J Ultrastruct Res. 1977; 60(2): 169-180, doi: 10.1016/s0022-5320(77)80063-4, indexed in Pubmed: 886640.

43. Pannese E. Biology and pathology of perineuronal satellite cells in sensory ganglia. Adv Anat Embryol Cell Biol. 2018: 1-63, doi: 10.1007/978-3-319-60140-3 1.

44. Pannese E. Electron microscopical study on the development of the satellite cell sheath in spinal ganglia. J Comp Neurol. 1969; 135(4): 381-422, doi: 10.1002/cne.901350403, indexed in Pubmed: 5768883.

45. Pannese E. Number and structure of perisomatic satellite cells of spinal ganglia under normal conditions or during axon regeneration and neuronal hypertrophy. Z Zellforsch. 1964; 63(4): 568-592, doi: 10.1007/bf00339491.

46. Pannese E. Observations on the morphology, submicroscopic structure and biological properties of satellite cells (s.c.) in sensory ganglia of mammals. Z Zellforsch. 1960; 
52: 567-597, doi: 10.1007/BF00339847, indexed in Pubmed: 13732495 .

47. Pannese E. The histogenesis of the spinal ganglia. Adv Anat Embryol Cell Biol. 1974; 47(5): 7-97, doi: 10.1007/978-3-66210338-8 2, indexed in Pubmed: 4420826.

48. Pannese $\bar{E}$. The response of the satellite and other non-neuronal cells to the degeneration of neuroblasts in chick embryo spinal ganglia. Cell Tissue Res. 1978; 190(1): 1-14, doi: 10.1007/ BF00210032, indexed in Pubmed: 688330.

49. Pannese E. The satellite cells of the sensory ganglia. Adv Anat Embryol Cell Biol. 1981, doi: 10.1007/978-3-642-67750-2.

50. Pannese $E$. The structure of the perineuronal sheath of satellite glial cells (SGCs) in sensory ganglia. Neuron Glia Biol. 2010; 6(1): 3-10, doi: 10.1017/S1740925X10000037, indexed in Pubmed: 20604977

51. Pérez Armendariz EM, Norcini M, Hernández-Tellez $B$, et al. Neurons and satellite glial cells in adult rat lumbar dorsal root ganglia express connexin 36. Acta Histochem. 2018; 120(3): 168-178, doi: 10.1016/j.acthis.2017.11.005, indexed in Pubmed: 29224922

52. Pilar G, Landmesser L. Ultrastructural differences during embryonic cell death in normal and peripherally deprived ciliary ganglia. J Cell Biol. 1976; 68(2): 339-356, doi: 10.1083/ jcb.68.2.339, indexed in Pubmed: 942724.

53. Procacci $P$, Magnaghi V, Pannese E. Perineuronal satellite cells in mouse spinal ganglia express the gap junction protein connexin43 throughout life with decline in old age. Brain Res Bull. 2008; 75(5): 562-569, doi: 10.1016/j.brainresbull.2007.09.007, indexed in Pubmed: 18355632.

54. Ramón y Cajal S. Histologie du système nerveux de I'homme \& des vertébrés. A. Maloine, Paris. 1909, doi: 10.5962/bhl. title.48637.

55. Rash JE, Yasumura T, Rash JE, et al. Direct immunogold labeling of aquaporin-4 in square arrays of astrocyte and ependymocyte plasma membranes in rat brain and spinal cord. Proc Natl Acad Sci USA. 1998; 95(20): 11981-11986, doi: 10.1073/ pnas.95.20.11981, indexed in Pubmed: 9751776.

56. Rashid $\mathrm{MH}$, Inoue $\mathrm{M}$, Matsumoto $\mathrm{M}$, et al. Switching of bradykinin-mediated nociception following partial sciatic nerve injury in mice. J Pharmacol Exp Ther. 2004; 308(3): 1158-1164, doi: 10.1124/jpet.103.060335, indexed in Pubmed: 14634040.

57. Reichelt M, Zerboni L, Arvin AM. Mechanisms of varicella-zoster virus neuropathogenesis in human dorsal root ganglia. J Virol. 2008; 82(8): 3971-3983, doi: 10.1128/JVI.02592-07, indexed in Pubmed: 18256143.

58. Rosenbluth J, Palay SL. The fine structure of nerve cell bodies and their myelin sheaths in the eighth nerve ganglion of the goldfish. J Biophys Biochem Cytol. 1961; 9: 853-877, doi: 10.1083/ jcb.9.4.853, indexed in Pubmed: 13743432

59. Sandelin M, Zabihi S, Liu Li, et al. Metastasis-associated S100A4 (Mts1) protein is expressed in subpopulations of sensory and autonomic neurons and in Schwann cells of the adult rat. J Comp Neurol. 2004; 473(2): 233-243, doi: 10.1002/cne.20115, indexed in Pubmed: 15101091

60. Schon F, Kelly JS. Autoradiographic localisation of [3H]GABA and [3H]glutamate over satellite glial cells. Brain Res. 1974; 66(2): 275-288, doi: 10.1016/0006-8993(74)90146-2.

61. Sharma K, Korade Z, Frank E. Late-migrating neuroepithelial cells from the spinal cord differentiate into sensory ganglion cells and melanocytes. Neuron. 1995; 14(1): 143-152, doi: 10.1016/08966273(95)90248-1, indexed in Pubmed: 7826632.

62. Shi TJS, Holmberg K, Xu ZQ, et al. Effect of peripheral nerve injury on CGMP and nitric oxide synthase levels in rat dorsal root ganglia: time course and coexistence. Pain. 1998; 78(3): 171-180, doi: 10.1016/s0304-3959(98)00124-9.

63. Shimeld C, Whiteland JL, Williams NA, et al. Cytokine production in the nervous system of mice during acute and latent infection with herpes simplex virus type 1. J Gen Virol. 1997; 78 (Pt 12): 3317-3325, doi: 10.1099/0022-1317-78-12-3317, indexed in Pubmed: 9400983.

64. Shimizu Y. The satellite cells in cultures of dissociated spinal ganglia. Z Zellforsch. 1965; 67(2): 185-195, doi: 10.1007/ BF00344468, indexed in Pubmed: 5327663.

65. Shinder V, Devor M. Structural basis of neuron-to-neuron cross-excitation in dorsal root ganglia. J Neurocytol. 1994; 23(9): 515-531, doi: 10.1007/BF01262054, indexed in Pubmed: 7815085 .
66. Thippeswamy T, McKay JS, Morris R, et al. Glial-mediated neuroprotection: evidence for the protective role of the NO-cGMP pathway via neuron-glial communication in the peripheral nervous system. Glia. 2005; 49(2): 197-210, doi: 10.1002/ glia.20105, indexed in Pubmed: 15390094.

67. Valentin G. Über den Verlauf und die letzten Enden der Nerven Nova acta phys med acad Caesar Leopol Carol Breslau u Bonn. 1836; 18: 51.

68. van Velzen M, Laman JD, Kleinjan A, et al. Neuron-interacting satellite glial cells in human trigeminal ganglia have an APC phenotype. J Immunol. 2009; 183(4): 2456-2461, doi: 10.4049/ jimmunol.0900890, indexed in Pubmed: 19635905.

69. Verbavatz JM, Ma T, Gobin R, et al. Absence of orthogonal arrays in kidney, brain and muscle from transgenic knockout mice lacking water channel aquaporin-4. J Cell Sci. 1997; 110 (Pt 22): 2855-2860, indexed in Pubmed: 9427293.

70. Vesin MF, Urade Y, Hayaishi O, et al. Neuronal and glial prostaglandin D synthase isozymes in chick dorsal root ganglia: a light and electron microscopic immunocytochemical study. J Neurosci. 1995; 15(1 Pt 1): 470-476, indexed in Pubmed: 7529829.

71. Vit JP, Jasmin L, Bhargava A, et al. Satellite glial cells in the trigeminal ganglion as a determinant of orofacial neuropathic pain. Neuron Glia Biol. 2006; 2(4): 247-257, doi: 10.1017/ s1740925x07000427, indexed in Pubmed: 18568096.

72. Wakisaka H, Kobayashi N, Mominoki K, et al. Herpes simplex virus in the vestibular ganglion and the geniculate ganglion: role of loose myelin. J Neurocytol. 2001; 30(8): 685-693, doi: 10.1023/a:1016577700280, indexed in Pubmed: 12118156.

73. Waxman SG, Dichter MA, Hartwieg EA, et al. Recapitulation of normal neuro-glial relations in dissociated cell cultures of dorsal root ganglia. Brain Res. 1977; 122(2): 344-350, doi: 10.1016/0006-8993(77)90300-6.

74. Wetmore C, Olson L. Neuronal and nonneuronal expression of neurotrophins and their receptors in sensory and sympathetic ganglia suggest new intercellular trophic interactions. J Comp Neurol. 1995; 353(1): 143-159, doi: 10.1002/cne.903530113, indexed in Pubmed: 7714245.

75. Wilkinson R, Leaver C, Simmons A, et al. Restricted replication of herpes simplex virus in satellite glial cell cultures clonally derived from adult mice. J Neurovirol. 1999; 5(4): 384-391, doi: 10.3109/13550289909029479, indexed in Pubmed: 10463860

76. Woodham P, Anderson PN, Nadim W, et al. Satellite cells surrounding axotomised rat dorsal root ganglion cells increase expression of a GFAP-like protein. Neurosci Lett. 1989; 98(1): 8-12, doi: 10.1016/0304-3940(89)90364-9, indexed in Pubmed: 2710403.

77. Wu HH, Bellmunt E, Scheib JL, et al. Glial precursors clear sensory neuron corpses during development via Jedi-1, an engulfment receptor. Nat Neurosci. 2009; 12(12): 1534-1541, doi: 10.1038/ nn.2446, indexed in Pubmed: 19915564.

78. Xian CJ, Zhou XF. Neuronal-glial differential expression of TGF-alpha and its receptor in the dorsal root ganglia in response to sciatic nerve lesion. Exp Neurol. 1999; 157(2): 317-326, doi: 10.1006/exnr.1999.7063, indexed in Pubmed: 10364443.

79. Young J, Brown DA, Kelly JS, et al. Autoradiographic localization of sites of [3H] -aminobutyric acid accumulation in peripheral autonomic ganglia. Brain Res. 1973; 63: 479-486, doi: 10.1016/0006-8993(73)90128-5.

80. Zerboni L, Arvin A. Neuronal subtype and satellite cell tropism are determinants of varicella-zoster virus virulence in human dorsal root ganglia xenografts in vivo. PLoS Pathog. 2015; 11(6): e1004989, doi: 10.1371/journal.ppat.1004989, indexed in Pubmed: 26090802.

81. Ziegler RJ, Herman RE. Peripheral infection in culture of rat sensory neurons by herpes simplex virus. Infect Immun. 1980; 28(2): 620-623, doi: 10.1128/iai.28.2.620-623.1980, indexed in Pubmed: 6249745.

82. Ziegler RJ, Pozos RS. Ultrastructural effects of herpes simplex virus type 2 infection of rat dorsal root ganglia in culture. J Neuropathol Exp Neurol. 1977; 36(4): 680-692, doi: 10.1097/00005072-197707000-00004, indexed in Pubmed: 196052.

83. Zimmerman E, Karsh D, Humbertson A. Initiating factors in perineuronal cell hyperplasia associated with chromatolytic neurons. Z Zellforsch. 1971; 114(1): 73-82, doi: 10.1007/ BF00339466, indexed in Pubmed: 5541844. 